\title{
Characterization of an acidic a-galactosidase from hemp (Cannabis sativa L.) seeds and its application in removal of raffinose family oligosaccharides (RFOs)
}

\author{
Weiwei Zhang1,2\#, Fang Du1\#, Guoting Tian³, Yongchang Zhao³, Hexiang Wang2 ${ }^{\circledR}$ \\ and Tzi Bun $\mathrm{Ng}^{4 \times}$ \\ IInstitute of Medicinal Plant Development, Chinese Academy of Medical Sciences \& Peking Union Medical College, Beijing 100193, PR China; \\ 2State Key Laboratory for Agrobiotechnology and Department of Microbiology, China Agricultural University, Beijing 100193, China; ${ }^{3}$ Institute of \\ Biotechnology and Germplasmic Resource, Yunnan Academy of Agricultural Science, Kunming 650223, China; ${ }^{4}$ School of Biomedical Sciences, \\ Faculty of Medicine, The Chinese University of Hong Kong, Shatin, New Territories, Hong Kong, China
}

An acidic a-galactosidase designated as hemp seed a-galactosidase (HSG) was purified from hemp (Cannabis sativa L.) seeds. By means of chromatographic procedures which involved chromatography on the cation-exchangers CM-cellulose and SP-Sepharose, chromatography on the anion-exchangers DEAE-cellulose and Q-Sepharose, and gel filtration on Superdex 75 using fast protein liquid chromatography, HSG was purified to electrophoretic homogeneity. Results of SDS-PAGE and gel filtration on FPLC Superdex 75 revealed that the enzyme was a monomeric protein with a molecular weight of $38 \mathrm{kDa}$. Sequences of the inner peptides of the a-galactosidase obtained by MALDI-TOF-MS showed that HSG was a novel a-galactosidase since there was a little similarity to the majority of a-galactosidases recorded in the literature. $\mathrm{A} \mathrm{pH}$ of 3.0 and a temperature of $50^{\circ} \mathrm{C}$ were optimal for the activity of the enzyme. The activity of HSG was inhibited by the chemical modification with N-bromosuccinimide (NBS) reagent. HSG contained 16 tryptophan residues and two tryptophan residues on the surface, which were crucial to the a-galactosidase activity. The heavy metal ions $\mathrm{Cd}^{2+}, \mathrm{Cu}^{2+}, \mathrm{Hg}^{2+}$ and $\mathrm{Zn}^{2+}$ inhibited its activity. The $K_{\mathrm{m}}$ and $V_{\max }$ for the hydrolysis of pNPGal (4-nitrophenyl $a-D$-galactopyranoside) were respective-

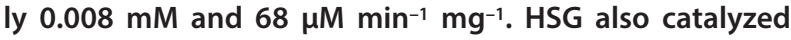
the hydrolysis of raffinose and other natural substrates. Hence the a-galactosidase possesses a tremendous potential for food and feed industries in the elimination of indigestible oligosaccharides from leguminous products.

Key words: a-galactosidases; Cannabis sativa L.; purification; raffinose family oligosaccharides

Received: 04 March, 2017; revised: 22 January, 2018; accepted: 15 July, 2018; available on-line: 08 September, 2018

更-mail: hxwang@cau.edu.cn (HW), b021770@mailserv.cuhk.edu. hk (TBN)

\#These authors contributed equally to this work.

Abbreviations: HSG, hemp seed a-galactosidase; FPLC, fast protein liquid chromatography; MALDI-TOF-MS, Matrix-Assisted Laser Desorption/ Ionization Time of Flight Mass Spectrometry; NBS, Nbromosuccinimide; pNPGal, 4-nitrophenyl a-D-galactopyranoside; RFOs, raffinose family oligosaccharides; DEPC, diethyl pyrocarbonate; DTT, dithiothreitol; EDC, carbodiimide; DIC, diacetyl; TNBS, 2, 4, 6-trinitrophenol

\section{INTRODUCTION}

Hemp (Cannabis sativa L.), an annual herbaceous plant, was grown as a fiber plant and an important food plant in ancient times (Li, 1974). Hemp seeds have an enor- mous number of possible applications, ranging from medical therapy to use in the textile industry. Hemp seeds display an abundant content of oil, protein, carbohydrates, insoluble fiber, $\beta$-carotene, antioxidant vitamins and minerals (Callaway, 2004). Selective breeding generated cannabis plants which can be employed for specific purposes, including high-potency marijuana strains and hemp cultivars for fiber and seed production (van Bakel et al., 2011). Cultivation of the marijuana strains has been banned because they contain high levels of tetrahydrocannabinol (THC), which is a psychoactive compound. Generally speaking, almost all other strains of hemp plants contain THC, albeit at a concentration much lower than that of marijuana strains. Recent research focused on the activity of compounds extracted from the high-THC strains (Appendino et al., 2008) and essential oils of industrial hemp varieties (Nissen et al., 2010) which display anti-microbial activity. The presence of abundant protein and other essential nutrients in hemp seeds indicates that they might be a new good source of nutrients for human beings (Galasso et al., 2016).

The oligosaccharides raffinose and stachyose, also referred to as raffinose family oligosaccharides (RFOs), accumulate in the large intestine of humans and other monogastric animals deficient in $\alpha$-galactosidase. This enzyme catalyzes the cleavage of the $\alpha-1,6$ galactosyl linkage in these oligosaccharides. The consequent accumulation of intact oligosaccharides in the large intestine results in microbial fermentation and then flatus formation (Steggerda, 1968). Purification and characterization of $\alpha$-galactosidases $(\alpha$-D-galactoside galactohydrolase, EC 3.2.1.22) which are widely distributed in microorganisms, plants, and animals was reported (Ramalingam et al., 2007; Wang et al., 2010; Singh \& Kayastha, 2012). $\alpha$-galactosidases exist in a diversity of plant seeds such as sunflower seeds, white chickpea and soybean (Porter et al., 1991; Kim et al., 2003; Singh \& Kayastha, 2012). The main function of $\alpha$-galactosidases in plants is to provide the energy during the seed development stage since $\alpha$-galactosidases can hydrolyze oligosaccharides (raffinose and stachyose) and polysaccharides to galactose. This hydrolytic ability is mainly employed in the sugar industry to improve sucrose crystallization by hydrolysing raffinose in beet sugar syrups (Patil et al., 2010; Ferreira et al., 2011). Despite its hydrolytic activity, $\alpha$-galactosidase is also used for oligosaccharide synthesis by transglycosylation (Goulas et al., 2009). Fabry disease is an $\mathrm{X}$-linked lysosomal storage disorder caused by mutations in the $\alpha$-galactosidase A gene (GLA), and the disease 
relatively often results in idiopathic hypertrophic cardiomyopathy which mimics the left ventricular hypertrophy (Andreotti et al., 2011; Nakagawa et al., 2011).

Hemp seeds are widely available and rich in protein, and represent an inexpensive source of $\alpha$-galactosidase. However, there are no published reports as yet. We herein report the purification and characterization of an acidic $\alpha$-galactosidase (HSG) from fiber hemp (Cannabis sativa L.) seeds using chromatographic procedures, which entailed cation-exchangers CM-cellulose and SP-Sepharose, anion-exchangers DEAE-cellulose and Q-Sepharose, and gel filtration on Superdex 75 using fast protein liquid chromatography. The properties of HSG could lay the foundation for using this enzyme in RFOs hydrolysis.

\section{MATERIALS AND METHODS}

Materials. Hemp seeds were bought in a market in Yunnan Province, China. DEAE-cellulose and CMcellulose were products of Sigma Chemical Company, USA while SP-Sepharose and Q-Sepharose were products of GE Healthcare, USA. Superdex 75 HR 10/30 and AKTA Purifier were from GE Healthcare, USA. The substrates, 4-nitrophenyl $\alpha$-D-galactopyranoside ( $\mathrm{pN}$ PGal), guar gum, locust bean gum, melibiose, raffinose and stachyose were from Sigma. All other chemicals used were of analytical grade.

Assay of $\alpha$-galactosidase activity. The standard assays of $\alpha$-galactosidase activity were executed following the pNPGal method as previously detailed (Rezende et al., 2005) with some modifications. The reaction mixture, composed of $50 \mu \mathrm{l}$ extract containing the enzyme and $50 \mu \mathrm{l} 10 \mathrm{mM}$ pNPGal (pH 3.6), was incubated at $50^{\circ} \mathrm{C}$ for $15 \mathrm{~min}$, then $0.5 \mathrm{M}$ sodium carbonate $(400$ $\mu l)$ was added to stop the reaction. The amount of p-nitrophenol released was determined by measuring the absorbance at $405 \mathrm{~nm}$. When other galacto-oligosaccharides (raffinose and stachyose) and polysaccharides (locust bean gum and guar gum) were used as the substrates, the amount of the formed reducing sugar was determined using 3,5-dinitrosalicylic acid method (Miller, 1959). A glucose oxidase method kit (GODPOD) was utilized to measure enzyme activity in the presence of melibiose. One unit of $\alpha$-galactosidase activity was defined as the amount of enzyme that produced $1 \mu \mathrm{mol}$ of $\mathrm{p}$-nitrophenol from galactose/glucose per minute. The enzyme activity was expressed as specific activity (units/mg of protein). Each reaction and the corresponding controls were performed in triplicate. Data represent means \pm S.D. $(n=3)$.

Purification of $\alpha$-galactosidase from hemp seeds. The hemp seeds (50 g) were washed and homogenized in saline $(500 \mathrm{~mL})$ by using a Waring blender. After overnight extraction at $4^{\circ} \mathrm{C}$, the seed homogenate was centrifuged $(12000 \times \mathrm{g})$ for $10 \mathrm{~min}$. Then $\left(\mathrm{NH}_{4}\right)_{2} \mathrm{SO}_{4}$ was added to the supernatant to $80 \%$ saturation. Five hours later, the mixture was centrifuged $(10000 \times g)$ for $10 \mathrm{~min}$. The precipitate was dissolved in distilled water and dialyzed to eliminate $\left(\mathrm{NH}_{4}\right)_{2} \mathrm{SO}_{4}$ prior to chromatography on a DEAE-cellulose column $(2.5 \mathrm{~cm} \times 20$ $\mathrm{cm})$ which had previously been equilibrated with 10 $\mathrm{mM}$ Tris-HCl buffer ( $\mathrm{pH}$ 8.6). Fractions D1, D2, D3 and D4 were eluted sequentially with $0 \mathrm{mM}, 100 \mathrm{mM}$, $200 \mathrm{mM}$ and $1 \mathrm{M} \mathrm{NaCl}$ in the starting buffer. $\alpha$-galactosidase activity was found in fraction D2 which was dialyzed against distilled water and then chromatographed on a column $(2.5 \mathrm{~cm} \times 10 \mathrm{~cm})$ of CM-cel- lulose equilibrated with $10 \mathrm{mM} \mathrm{NaAc-HAc}$ buffer $(\mathrm{pH}$ 4.0). Unadsorbed proteins were eluted with the starting buffer while adsorbed proteins were desorbed by addition of $100 \mathrm{mM}, 300 \mathrm{mM}$ and $1 \mathrm{M} \mathrm{NaCl}$ successively in the starting buffer. After the dialysis, the fraction (CM3) with activity was chromatographed on a column of Q-Sepharose $(0.5 \mathrm{~cm} \times 20 \mathrm{~cm})$ previously equilibrated with $10 \mathrm{mM}$ Tris-HCl buffer (pH 8.6). After the removal of unadsorbed proteins with the starting buffer, the column was eluted with $100 \mathrm{mM} \mathrm{NaCl}$ in the starting buffer to yield the active fraction (Q2). It was then further separated by ion exchange chromatography on an SP-Sepharose column $(0.5 \mathrm{~cm} \times 10 \mathrm{~cm})$. After unadsorbed proteins (fraction SP1) all came off the column in $10 \mathrm{mM} \mathrm{NaAc-HAc}$ buffer (pH 4.6), the column was eluted with a linear gradient of $0-300 \mathrm{mM} \mathrm{NaCl}$ in the same buffer. The active peak (SP2) was finally chromatographed on a Superdex G-75 HR10/30 column by fast protein liquid chromatography using an AKTA Purifier (GE Healthcare, US)

Determination of molecular mass of the isolated $\alpha$-galactosidase. SDS-PAGE of the isolated $\alpha$-galactosidase was conducted in a $12 \%$ acrylamide gel at $\mathrm{pH} 8.8$ using $25 \mathrm{mM}$ Tris-glycine buffer containing $0.1 \%(\mathrm{w} / \mathrm{v})$ SDS as reported before (Laemmli\&Favre, 1973). The gels were stained in $0.1 \%$ $(\mathrm{w} / \mathrm{v})$ Coomassie blue, $30 \%(\mathrm{v} / \mathrm{v})$ methanol and $10 \%$ $(\mathrm{v} / \mathrm{v})$ acetic acid in water. Electrophoretic mobility of the isolated $\alpha$-galactosidase was compared to that of PageRuler Unstained Protein Ladder (Thermo Fisher) and the molecular mass was estimated from the calibration curve of electrophoretic mobility against molecular mass. The gels were then destained in the above-mentioned solution without Coomassie blue. The molecular weight was also estimated by using gel filtration on an FPLC Superdex 75 HR10/30 column (GE Healthcare).

Analysis of the amino acid sequence of the isolated $\alpha$-galactosidase. The isolated $\alpha$-galactosidase was digested with trypsin and subjected to analysis by MALDITOF-MS. Some high-quality peptides were subsequently analyzed by ESI-MS/MS. Amino acid sequences of the inner peptides were obtained using MALDI-TOF-MS and ESI-MS/MS.

Biochemical properties of the isolated $\alpha$-galactosidase. Biochemical properties of HSG was determined according to the method of Zhang et al. (2015) with slight modifications, including the effects of $\mathrm{pH}$, temperature, metal ions and chemical modification reagents on the enzyme activity.

The optimal $\mathrm{pH}$ for the enzyme was assayed at $50^{\circ} \mathrm{C}$ in the $\mathrm{pH}$ range from 2.0 to 8.0 in $100 \mathrm{mM} \mathrm{Na}_{2} \mathrm{H}$ $\mathrm{PO}_{4}$-citric acid buffer. To determine $\mathrm{pH}$ stability the enzyme was incubated at room temperature for $1 \mathrm{~h}$ in buffers of various $\mathrm{pH}$ values. The residual $\alpha$-galactosidase activity was determined using the aforementioned enzyme assay conditions.

The activity of the isolated enzyme at the optimum $\mathrm{pH}$ was determined in the temperature range from 4 to $60^{\circ} \mathrm{C}$. The optimal temperature for the enzyme could thus be ascertained. The temperature stability of the purified $\alpha$-galactosidase was measured after incubation at different temperatures for $30 \mathrm{~min}$ and subsequent determination of the residual $\alpha$-galactosidase activity under the standard conditions.

The influence of different concentrations $(1.25,2.5,5$, and $10 \mathrm{mM})$ of chloride salts of the metal ions $\left(\mathrm{Mg}^{2+}\right.$, $\mathrm{Hg}^{2+}, \mathrm{Mn}^{2+}, \mathrm{Pb}^{2+}, \mathrm{Fe}^{2+}, \mathrm{Fe}^{3+}, \mathrm{Ca}^{2+}, \mathrm{Cu}^{2+}, \mathrm{K}^{+}, \mathrm{Cd}^{2+}, \mathrm{Zn}^{2+}$, $\mathrm{Al}^{3+}$ ) on the isolated $\alpha$-galactosidase activity was exam- 
Table 1. Summary of purification procedure of hemp seeds (from $50 \mathrm{~g}$ hemp seeds)

\begin{tabular}{lccccc}
\hline Purification step & $\begin{array}{c}\text { Yield } \\
(\mathrm{mg})\end{array}$ & $\begin{array}{c}\text { Total activity } \\
(\mathrm{U})^{\mathrm{a}}\end{array}$ & $\begin{array}{c}\text { Specific activity } \\
(\mathrm{U} / \mathrm{mg})^{\mathrm{b}}\end{array}$ & $\begin{array}{c}\text { Recovery rate } \\
(\%)\end{array}$ & Purification foldc \\
\hline Crude extract & 233.2 & 12400 & 53.1 & 100 & 1 \\
\hline Ammonium sulfate precipitate & 76 & 9049.3 & 119.0 & 72.9 & 2.2 \\
\hline D2 & 24.7 & 4935.0 & 199.8 & 39.7 & 3.7 \\
\hline CM3 & 5.29 & 3051.9 & 576.9 & 24.6 & 10.8 \\
\hdashline Q2 & 2.37 & 1828.5 & 771.5 & 14.7 & 14.5 \\
\hline SP2 & 1.27 & 1131.4 & 890.8 & 9.1 & 16.7 \\
\hline SU1 & 0.128 & 182.8 & 1428.5 & 1.4 & 26.8 \\
\hline
\end{tabular}

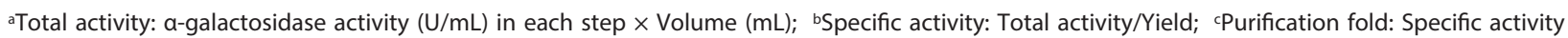
of each step/Specific activity of the first step.

ined. The effects of chemical modification reagents comprising N-bromosuccinimide (NBS), diethyl pyrocarbonate (DEPC), dithiothreitol (DTT), carbodiimide (EDC), diacetyl (DIC) and 2, 4, 6-trinitrophenol (TNBS) on $\alpha$-galactosidase activity were also investigated. The enzyme was incubated with various metal ions and chemical modification reagents at $4^{\circ} \mathrm{C}$ for 2 hours and then the residual $\alpha$-galactosidase activity was assayed. The activity of the enzyme without any additive was taken as $100 \%$.

Each reaction and the corresponding controls were performed in triplicate.

Determination of tryptophan residues number in the isolated $\alpha$-galactosidase. NBS was dissolved in 10 $\mathrm{mM}$ NaAc-HAc buffer ( $\mathrm{pH} 4.5$ ). The number of modified tryptophan residues was determined spectrophotometrically according to the method of Spande using the following equation (Spande \& Witkop, 1967):

$\mathrm{n}=\Delta \mathrm{A} \times 1.31 \times M_{\mathrm{r}} \times \mathrm{V} /(\mathrm{W} \times 5500)$

where: $\Delta \mathrm{A}$ is the difference in absorbance between the native and the tryptophan-modified enzyme.1.31 is an empirical factor, 5500 is the molar extinction coefficient for $\operatorname{Trp}\left(\mathrm{M}^{-1} \mathrm{~cm}^{-1}\right)$, Mr is the molecular mass of the isolated $\alpha$-galactosidase, and $\mathrm{V}$ is the reaction volume.

For modifying the tryptophan residues in the interior of the enzyme molecule, the enzyme solution mixed with $8 \mathrm{M}$ urea was boiled for $5 \mathrm{~min}$. Then different quantities of NBS $(4 \mathrm{mM})$ were added to modify the mixture until the absorbance at $280 \mathrm{~nm}$ reached the minimum value. The total number of tryptophan residues was calculated using the abovementioned formula. For determination of the tryptophan residues on the isolated $\alpha$-galactosidase surface, a similar method was used except for the treatment with urea (Du et al., 2013).

Substrate specificity and kinetic studies. For ascertaining the substrate specificity of the isolated $\alpha$-galactosidase, the activity of the enzyme in the presence of different types of substrate, encompassing the synthetic substrate pNPGal, oligosaccharides (raffinose, melibiose, stachyose) and galactomannans (locust bean gum and guar gum) was determined in accordance with the methods described above.

The $K_{\mathrm{m}}$ and $V_{\max }$ of purified $\alpha$-galactosidase were determined using substrates pNPGal (1-10 mM) and raffinose $(50-300 \mathrm{mM})$ in $0.1 \mathrm{M} \mathrm{Na}_{2} \mathrm{HPO}_{4}$-citric acid buffer at $30^{\circ} \mathrm{C}$ with the pNPGal method or DNS method. The apparent Michaelis constant $\left(K_{\mathrm{m}}\right)$ and $V_{\max }$ were calculated from the Lineweaver-Burk plot which was cre- ated using the initial rates obtained at various substrate concentrations and constant amount of the enzyme.

Statistical analysis. The data were analyzed by SPSS version 24.0 for Windows (SPSS Inc., Chicago, IL, USA). Results were represented as the mean \pm standard deviation (S.D.).

\section{RESULTS}

\section{Isolation of hemp seed a-galactosidase and determination of its molecular mass and inner-peptide sequence}

HSG was purified from hemp seeds by employing a protocol that comprised, sequentially, precipitation with $80 \%$ saturated ammonium sulfate, and chromatographic separation on anion exchanger DEAE-cellulose, cation exchanger CM-cellulose, anion exchanger Q-Sepharose, and cation exchanger SP-Sepharose. $\alpha$-galactosidase activity was found in peaks D2, CM3, Q2, and SP2 (Table 1). The purified fraction SU1 was obtained by size exclusion chromatography of SP2 on a Superdex G-75 HR 10/30 column (Fig. 1). The results of the purification of hemp seed $\alpha$-galactosidase were summarized in Table 1. HSG displayed a molecular mass of $38 \mathrm{kDa}$ as estimated by SDS-PAGE (Fig. 2) and gel filtration (Fig. 1). The amino acid sequences of three inner pep-

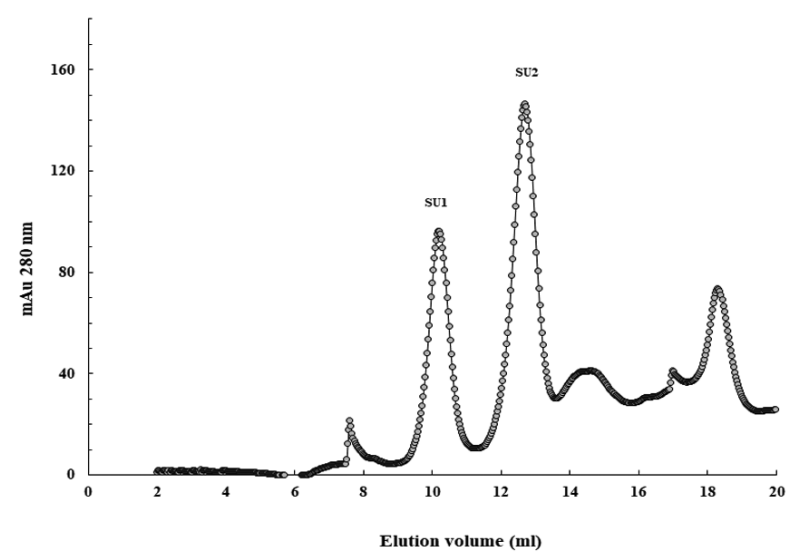

Figure 1. Gel filtration of SP2 on a Superdex 75 HR10/30 column.

The molecular mass of SU1 was $38 \mathrm{kDa}$. 


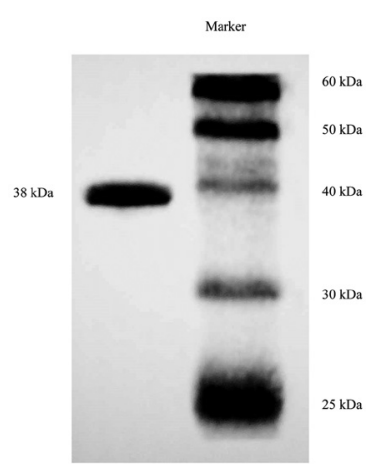

Figure 2. SDS-PAGE results.

Left lane: fraction SU1 representing purified hemp seed a-galactosidase. Right lane: molecular mass standard. The molecular mass of SU1 was $38 \mathrm{kDa}$.

tides as determined by ESI-MS/MS were LFGVT'TLDVVR, TQDGGTEVVEAK and DDLFNINAGIVK.

\section{Physiochemical properties of purified hemp seed a-galactosidase}

Hemp seed $\alpha$-galactosidase demonstrated optimal activity at pH 3.0 (Fig. 3A). It was stable only at $\mathrm{pH} 2-4$ (Fig. 3B). There was an abrupt fall in activity (about $60 \%$ reduction) when the $\mathrm{pH}$ reached 5 . No activity could be detected in alkaline $\mathrm{pH}$. The optimum temperature for $\mathrm{HSG}$ activity was $50^{\circ} \mathrm{C}$ (Fig. 3C), but about $65 \%$ of the initial activity was lost after incubation at $50^{\circ} \mathrm{C}$ for $60 \mathrm{~min}$ (Fig. 3D). The metal ions $\mathrm{Cd}^{2+}, \mathrm{Cu}^{2+}, \mathrm{Hg}^{2+}$ and $\mathrm{Zn}^{2+}$ strongly inhibited the activity of HSG, whereas $\mathrm{Mg}^{2+}$ and $\mathrm{Pb}^{2+}$ ions partially inhibited the enzyme activity in this study (Table 2). The effects of six chemical modification reagents (NBS, DEPC, DT', EDC, DIC, TNBS) on the activity of
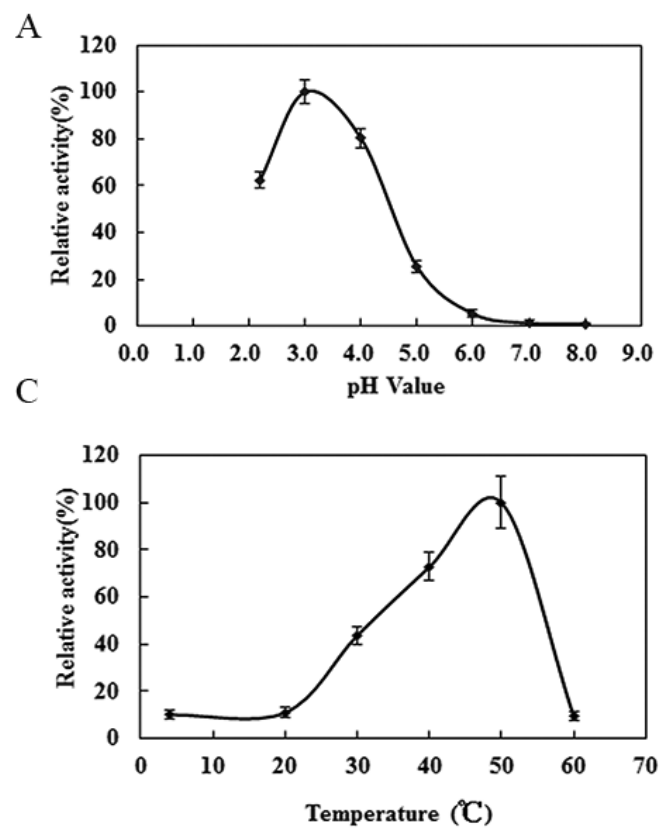

Table 2. Effects of metal ions on activity of hemp seed a-galactosidase (results represent mean \pm S.D., $n=3$ )

\begin{tabular}{ccccc}
\hline \multirow{2}{*}{$\begin{array}{l}\text { Metal ion } \\
\text { concentration }\end{array}$} & \multicolumn{4}{c}{ Relative galactosidase activity (\%) } \\
\cline { 2 - 5 } & $10 \mathrm{mM}$ & $5 \mathrm{mM}$ & $2.5 \mathrm{mM}$ & $1.25 \mathrm{mM}$ \\
\hline $\mathrm{Fe}^{2+}$ & $102 \pm 0.02$ & $97 \pm 0.01$ & $102 \pm 0.01$ & $77 \pm 0.02$ \\
\hdashline $\mathrm{K}^{+}$ & $100 \pm 0$ & $89 \pm 0.01$ & $83 \pm 0.04$ & $84 \pm 0.01$ \\
\hdashline $\mathrm{Ca}^{2+}$ & $99 \pm 0.03$ & $76 \pm 0.01$ & $93 \pm 0.02$ & $97 \pm 0$ \\
\hdashline $\mathrm{Cd}^{2+}$ & $0 \pm 0$ & $4 \pm 0.01$ & $5 \pm 0.01$ & $11 \pm 0$ \\
\hdashline $\mathrm{Cu}^{2+}$ & $0 \pm 0$ & $1 \pm 0.01$ & $4 \pm 0.01$ & $2 \pm 0.01$ \\
\hdashline $\mathrm{Hg}^{2+}$ & $0 \pm 0.01$ & $2 \pm 0.01$ & $0 \pm 0.01$ & $4 \pm 0.01$ \\
\hdashline $\mathrm{Mg}^{2+}$ & $71 \pm 0.01$ & $58 \pm 0.05$ & $64 \pm 0.01$ & $85 \pm 0.02$ \\
\hdashline $\mathrm{Mn}^{2+}$ & $111 \pm 0.09$ & $108 \pm 0.01$ & $76 \pm 0.01$ & $69 \pm 0.01$ \\
\hdashline $\mathrm{Pb}^{2+}$ & $76 \pm 0.02$ & $42 \pm 0.01$ & $30 \pm 0$ & $43 \pm 0.01$ \\
\hdashline $\mathrm{Zn}^{2+}$ & $8 \pm 0.01$ & $6 \pm 0$ & $26 \pm 0$ & $32 \pm 0.01$ \\
\hdashline $\mathrm{Al}^{3+}$ & $136 \pm 0$ & $121 \pm 0.02$ & $112 \pm 0$ & $122 \pm 0.01$ \\
\hdashline $\mathrm{Fe}^{3+}$ & $128 \pm 0.01$ & $103 \pm 0.1$ & $45 \pm 0.3$ & $78 \pm 0.01$ \\
\hline
\end{tabular}

hemp seed $\alpha$-galactosidase were tested. Only NBS had an obvious effect. After incubation with $0.1 \mathrm{mM}$ NBS for $30 \mathrm{~min}$, the enzyme lost all $\alpha$-galactosidase activity (Fig. 4). When $90 \mu \mathrm{l}$ NBS was added to the completely denatured enzyme, A280nm reached the minimum value which demonstrated that the tryptophan residues
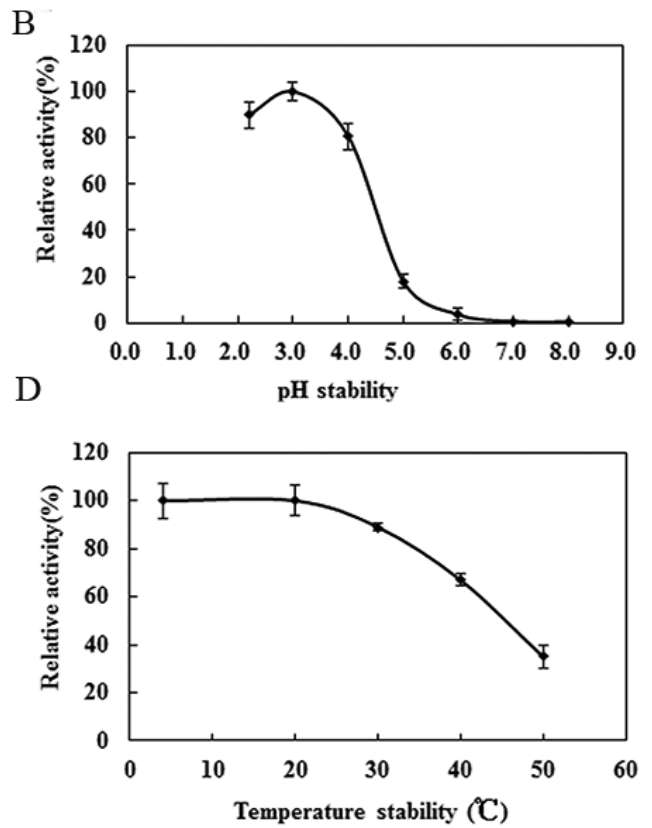

Figure 3. Characterization of the enzymatic properties of HSG.

(A) Effect of $\mathrm{pH}$ on a-galactosidase activity was determined at $50^{\circ} \mathrm{C}$ in buffers ranging from $\mathrm{pH} 2.0$ to 8.0 . The activity obtained at $\mathrm{pH}$ 3.0 was taken as $100 \%$. (B) pH stability of a-galactosidase activity was determined by measuring a-galactosidase activity under standard assay conditions (pNPGal) after pre-incubation of the enzyme at room temperature for 60 min in buffers with pH ranging from 2.0 to 8.0. The activity of an enzyme sample at pH 3.0 was defined as $100 \%$. (C) Effect of temperature on a-galactosidase activity was determined at $4-60^{\circ} \mathrm{C}$. The activity obtained at $50^{\circ} \mathrm{C}$ was taken as $100 \%$. (D) Thermostability of a-galactosidase activity was determined after pre-incubation of the enzyme at different temperatures ranging from $4-50^{\circ} \mathrm{C}$ for $60 \mathrm{~min}$. The activity of enzyme sample under $4^{\circ} \mathrm{C}$ was defined as $100 \%$. Data represent means \pm S.D. $(n=3)$. 


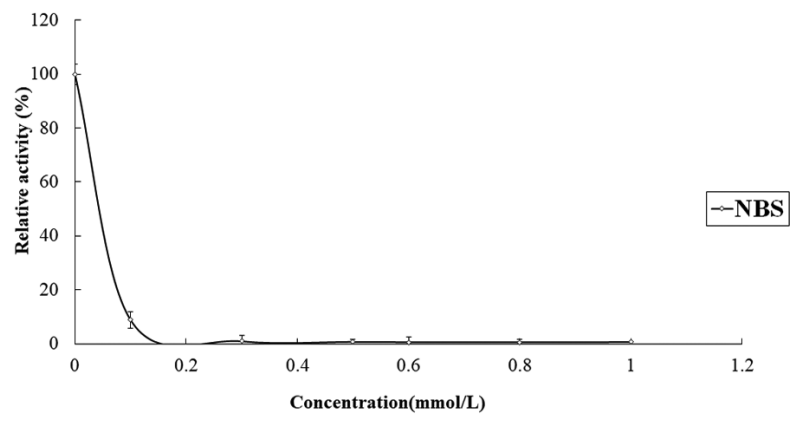

Figure 4. Effect of chemical modification agent NBS on hemp seed a-galactosidase activity.

The data were reproducible among the experiment replicates. Data represent means \pm S.D. $(n=3)$. NBS, N-bromo-succinamide

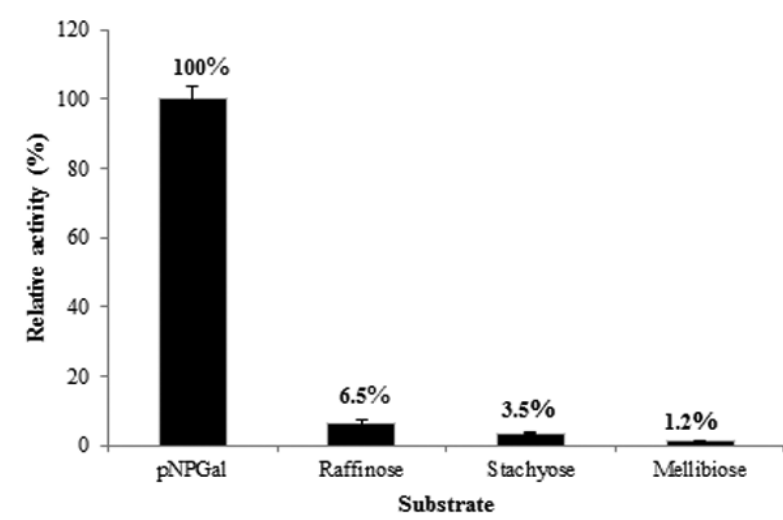

Figure 5. Hydrolysis of natural and synthetic substrates by HSG. Data represent means \pm S.D. $(n=3)$.

were modified completely. The total number of tryptophan residues was calculated by the formula. HSG contained 16 tryptophan residues. The different concentrations of NBS modifying the enzyme solution can be used to calculate the number of tryptophan residues on the HSG surface. Our analysis revealed that there are two tryptophan residues on the HSG surface. Hemp seed $\alpha$-galactosidase exhibited the highest specificity toward pNPGal. As compared to pNPGal (100\%), the enzyme manifested lower activity toward raffinose $(6.3 \%)$, stachyose $(3.5 \%)$ and melibiose $(1.2 \%)$ (Fig. 5). The $K_{\mathrm{m}}$ and $V_{\max }$ values for hemp seed $\alpha$-galactosidase were $0.008 \mathrm{mM}^{\max }$ and $68 \mu \mathrm{M} \mathrm{min} \mathrm{mg}^{-1}$ for the hydrolysis of pNPGal and $0.16 \mathrm{mM}$ and $4.3 \mu \mathrm{mol} \mathrm{min} \mathrm{mg}^{-1}$ for the hydrolysis of raffinose, respectively.

\section{DISCUSSION}

HSG was purified from hemp seeds by a series of purification steps. The specific activity of $\alpha$-galactosidase toward pNPGal after 26.8-fold purification was 1428.5 $\mathrm{U} / \mathrm{mg}$ with a final yield of $1.4 \%$ which exceeded those of $\alpha$-galactosidases from Bispora sp. MEY-1 (Wang et al., 2010), Penicillium purpurogenum (Shibuya et al., 1998) and white chickpea (Singh\&Kayastha, 2012).

It was a monomeric protein with a molecular mass of $38 \mathrm{kDa}$ that resembled the $\alpha$-galactosidases from germinating lentil (Lens culinaris) seeds (40 kDa) (Celem et al., 2009) and Pichia pastoris (41 kDa) (Gao et al., 2003). Nevertheless, some $\alpha$-galactosidases have a substantially larger molecular mass, such as $\alpha$-galactosidases from $A$ spergillus terreus (108 kDa) (Shankar et al., 2009) and Pleurotus florida (99 kDa) (Ramalingam et al., 2007).

The amino acid sequences of three inner peptides were determined by ESI-MS/MS. The sequences were LFGVTTLDVVR, TQDGGTEVVEAK and DDLFNINAGIVK which exhibited some homology with $\alpha$-galactosidases from other species, with the highest extent of homology $(64 \%)$ with $\alpha$-galactosidase from Treponema azotonutricium (not shown). There is a little identity with other $\alpha$-galactosidases, suggesting that hemp seed $\alpha$-galactosidase is a new enzyme.

It is crucial to understand the properties of this enzyme, as it can be used in production. Using pNPGal as the substrate, the activity of HSG reached its maximum at $\mathrm{pH} 3.0$ and the enzyme was stable only at acidic conditions. This was typical for $\alpha$-galactosidases which usually have optima at acidic $\mathrm{pH}$ values. Many fungal $\alpha$-galactosidases such as those from Rhizopus sp. demonstrated an optimum pH of 4.8 (CaO et al., 2009). $\alpha$-galactosidase of the fungus Thermomyces lanuginosus displayed a pH optimum of 5-5.5 (Rezessy-Szabo et al., 2007). So did the $\alpha$-galactosidase from the white-rot fungus Pleurotus florida (Ramalingam et al., 2007).

HSG exhibited maximum activity at $50^{\circ} \mathrm{C}$, about $65 \%$ of the initial activity was lost after incubation at $50^{\circ} \mathrm{C}$ for $60 \mathrm{~min}$, which was analogous to the $\alpha$-galactosidases from Penicillium sp. F63 CGMCC1669 and Rhiropus sp. F78 ACCC 30795 which showed low temperature opti$\mathrm{ma}$ at 40 and $50^{\circ} \mathrm{C}$, respectively, as well as low thermostability (Mi et al., 2007; Cao et al., 2009).

The metal ions $\mathrm{Cd}^{2+}, \mathrm{Cu}^{2+}, \mathrm{Hg}^{2+}$ and $\mathrm{Zn}^{2+}$ strongly inhibited the activity of HSG, whereas $\mathrm{Mg}^{2+}$ and $\mathrm{Pb}^{2+}$ ions partially inhibited the enzyme activity in this study. Shankar reported that $\mathrm{Ag}^{+}, \mathrm{Hg}^{2+}$ and $\mathrm{Cu}^{2+}$ ions completely eliminated the activity of a thermostable $\alpha$-galactosidase from Aspergillus terreus (GR) strain (Shankar et al., 2009). $\alpha$-galactosidase from Cucurbita pepo leaves was partially inhibited by $\mathrm{Ca}^{2+}, \mathrm{Mg}^{2+}$ and $\mathrm{Mn}^{2+}$ ions, more so by $\mathrm{Ni}^{2+}, \mathrm{Zn}^{2+}$ and $\mathrm{Co}^{2+}$ ions, and severely inhibited by $\mathrm{Cu}^{2+}, \mathrm{Ag}^{+}$and $\mathrm{Hg}^{2+}$ ions (Gaudreault\&Webb, 1983). Thus, $\alpha$-galactosidases from different sources are similar in their inhibition by $\mathrm{Hg}^{2+}$ and $\mathrm{Cu}^{2+}$ ions.

Among the six chemical modification reagents, only NBS had an obvious effect on hemp seed $\alpha$-galactosidase. NBS is a reagent modifying the tryptophan in the protein. Incubation of the enzyme with $0.1 \mathrm{mM}$ NBS for $30 \mathrm{~min}$ resulted in total loss of $\alpha$-galactosidase activity, signifying that tryptophan is an amino acid essential to the enzyme activity. The results were reminiscent of similar data on $\alpha$-galactosidase from germinating coffee beans (Shen \& Jin, 2011).

HSG contained 16 tryptophan residues including and two tryptophan residues on its surface. NBS-modification resulted in the formation of oxidized surface tryptophan residues that did not relocate to the hydrophobic interior. These results suggest that native surface tryptophan residues play a pivotal role in the activity of HSG. Thus, one can assume that these surface tryptophan residues reside in the active site. The other 14 tryptophan residues may be located on the interior of the hemp seed $\alpha$-galactosidase molecule. There are several studies on the detection of tryptophan residues on enzymes by NBS modification. Teng reported that hyaluronidase contained 11 tryptophan residues, only one of which was essential for the activity of the enzyme (Teng et al., 2006). There are 17 tryptophan residues on inulinase and 2 of them play a pivotal role in the enzymatic activity (Liu et al., 2007). 
HSG showed the highest specificity for pNPGal. Generally, $\alpha$-galactosidase exhibited higher activity with the synthetic substrate ( $\mathrm{pNPGal}$ ) compared to natural substrates (melibiose, raffinose and stachyose) (Ferreira et al., 2011), HSG did not act on the polysaccharides, locust bean gum and guar gum. According to their substrate specificities, $\alpha$-galactosidases can be divided into two groups (Dey et al., 1993). The first group contains $\alpha$-galactosidases active only on oligosaccharides with a low degree of polymerization, for example melibiose, raffinose and stachyose. The second group of $\alpha$-galactosidases consists of enzymes active on polymeric substrates and short oligosaccharides (Comfort et al., 2007). The inability of HSG to act on polymeric substrates such as locust bean gum and guar gum was possibly due to the large, multimeric structure of $\alpha$-galactosidase which restricts the accessibility of polymeric substrates to the enzyme active site.

The Michaelis constant for pNPGal determined in the kinetic experiments was considerably lower than the corresponding value for raffinose; however, it is evident that synthetic substrates are hydrolyzed more efficiently than natural galacto-oligosaccharides by most $\alpha$-galactosidases.

\section{CONCLUSION}

In this study, an acidic $\alpha$-galactosidase from hemp (Cannabis sativa L.) seeds was purified and characterized for the first time. The molecular mass of the hemp seed $\alpha$-galactosidase as determined by SDS-PAGE and gel-filtration was $38 \mathrm{kDa}$. The isolated $\alpha$-galactosidase demonstrated pronounced activity and stability at acidic $\mathrm{pH}$ values, which makes it valuable for applications at these $\mathrm{pH}$ values. The $\alpha$-galactosidase contained 16 tryptophan residues with two of them located on the surface and playing a key role in the activity of the enzyme. The purified enzyme could efficiently hydrolyze natural substrates such as raffinose. The results suggest that hemp seed $\alpha$-galactosidase has tremendous potential in the beet sugar and food and feed industries for the elimination of indigestible oligosaccharides from legumes.

\section{Declaration of interest}

We declare that we have no conflict of interest.

\section{Author Contributions}

H. Wang designed the study. G. Tian and Y. Zhao prepared materials and reagents. W. Zhang and F. Du performed the experiment. $\mathrm{T}$. B. $\mathrm{Ng}$ wrote the manuscript. All authors reviewed the manuscript.

\section{Acknowledgments of Finnacial Support}

This work was financially supported by Special Fund for Agro-scientific Research in the Public Interest No. 201303080) and National Natural Science Foundation of China (NSFC) (No. 81374071 and No. 81573703).

\section{REFERENCES}

Andreotti G, Citro V, De Crescenzo A, Orlando P, Cammisa M, Correra A, Cubellis MV (2011) Therapy of Fabry disease with pharmacological chaperones: from in silico predictions to in vitro tests. Orphanet J Rare Dis 6. doi: 10.1186/1750-1172-6-66

Appendino G, Gibbons S, Giana A, Pagani A, Grassi G, Stavri M, Smith E, Rahman MM (2008) Antibacterial cannabinoids from Cannabis sativa: a structure-activity study. J Nat Prod 71: 1427-1430. doi: $10.1021 / \mathrm{np} 8002673$
Callaway JC (2004) Hempseed as a nutritional resource: An overview Euphytica 140: 65-72. doi: 10.1007/s10681-004-4811-6

Cao Y, Wang Y, Luo H, Shi P, Meng K, Zhou Z, Zhang Z, Yao B (2009) Molecular cloning and expression of a novel protease-resistant GH-36 alpha-galactosidase from Rhiropus sp. F78 ACCC 30795. J Microbiol Biotechn 19: 1295-1300

Celem EB, Bolle SS, Onal S (2009) Efficient and rapid purification of lentil alpha-galactosidase by affinity precipitation with alginate. Indian J Biochem Bio 46: 366-370

Comfort DA, Bobrov KS, Ivanen DR, Shabalin KA, Harris JM, Kulminskaya AA, Brumer H, Kelly RM (2007) Biochemical analysis of Thermotoga maritima GH36 alpha-galactosidase (TmGalA) confirms the mechanistic commonality of clan GH-D glycoside hydrolases Biochemistry 46: 3319-3330. doi: 10.1021/bi061521n

Dey PM, Patel S, Brownleader MD (1993) Induction of alpha-galactosidase in Penicillium ochrochloron by guar (Cyamopsis tetragonobola) gum. Biotechnol Appl Bioc 17: 361-371

Du F, Zhu MJ, Wang HX, Ng T (2013) Purification and characterization of an alpha-galactosidase from Phaseolus coccineus seeds showing degrading capability on raffinose family oligosaccharides. Plant Physiol Bioch 69: 49-53. doi: 10.1016/j.plaphy.2013.04.017

Ferreira JG, Reis AP, Guimaraes VM, Falkoski DL, Fialho LD, de Rezende ST (2011) Purification and characterization of Aspergillus terreus alpha-galactosidases and their use for hydrolysis of soymilk oligosaccharides. Appl Biochem Biotech 164: 1111-1125. doi: 10.1007/ s12010-011-9198-y

Galasso I, Russo R, Mapelli S, Ponzoni E, Brambilla IM, Battelli G, Reggiani R (2016) Variability in seed traits in a collection of Cannabis sativa L. genotypes. Frontiers Plant Sci 7: 688. doi: 10.3389/ fpls.2016.00688

Gao X, Yang J, Li SB, Liu ZP, Zhang YP (2003) Fermentation and purification of recombinant alpha-galactosidase from Pichia pastoris. Chinese J Biotechnol 19: 223-226

Gaudreault PR, Webb JA (1983) Partial purification and properties of an alkaline alpha-galactosidase from mature leaves of Cucurbita pepo. Plant Physiol 71: 662-668

Goulas T, Goulas A, Tzortzis G, Gibson GR (2009) A novel alphagalactosidase from Bifidobacterium bifidum with transgalactosylating properties: gene molecular cloning and heterologous expression. Appl Microbiol Biot 82: 471-477. doi: 10.1007/s00253-008-1750-5

Kim WD, Kaneko S, Park GG, Tanaka H, Kusakabe I, Kobayashi H (2003) Purification and characterization of alpha-galactosidase from sunflower seeds. Biotechnol Lett 25: 353-358

Laemmli UK, Favre M (1973) Maturation of the head of bacteriophage T4. I. DNA packaging events. J Mol Biol 80: 575-599

Li HL (1974) Origin and use of cannabis in eastern asia linguistic-cultural implications. Econ Bot 28: 293-301. doi: 10.1007/Bf02861426

Liu X, Gao GF, Yang L, Xiao-Xiao HE, Meng Z, Teng LR (2007) Tryptophan modification and fluorescence spectrum of inulinase. Chem J Chinese Univ 28: 103-105

Mi SJ, Bai YG, Meng K, Wang YR, Yao B, Shi XY, Huang HQ, Zhang YH, Shi PJ (2007) Purification and characterization of a novel alpha-galactosidase from penicillium sp. F63 CGMCC1669. Acta Microbiol Sin 47: 156-160

Miller GL (1959) Use of dinitrosalicylic acid reagent for determination of reducing sugar. Anal Chem 31: 426-428. doi: 10.1021/ Ac60147a030

Nakagawa N, Maruyama H, Ishihara T, Seino U, Kawabe J, Takahashi F, Kobayashi M, Yamauchi A, Sasaki Y, Sakamoto N, Ota H, Tanabe Y, Takeuchi T, Takenaka T, Kikuchi K, Hasebe N (2011) Clini$\mathrm{cal}$ and genetic investigation of a Japanese family with cardiac fabry disease. Identification of a novel alpha-galactosidase A missense mutation (G195V). Int Heart J 52: 308-311

Nissen L, Zatta A, Stefanini I, Grandi S, Sgorbati B, Biavati B, Monti A (2010) Characterization and antimicrobial activity of essential oils of industrial hemp varieties (Cannabis sativa L.). Fitoterapia 81: 413419. doi: 10.1016/j.fitote.2009.11.010

Patil AG, K PK, Mulimani VH, Veeranagouda Y, Lee K (2010) alphaGalactosidase from Bacillus megaterium VHM1 and its application in removal of flatulence-causing factors from soymilk. I Microbiol Biotechn 20: 1546-1554

Porter JE, Ladisch MR, Herrmann KM (1991) Ion exchange and affinity chromatography in the scaleup of the purification of alphagalactosidase from soybean seeds. Biotechnol Bioeng 37: 356-363. doi: 10.1002/bit.260370409

Ramalingam, Saraswathy N, Sadasivam S, Subha K, Poorani N (2007) Purification and properties of alpha-galactosidase from white-rot fungus Pleurotus florida. Indian J Biochem Bio 44: 76-81

Rezende STD, Guimarães VM, Rodrigues MDC, Felix CR (2005) Purification and characterization of an $\alpha$-galactosidase from Aspergillus fumigatus. Braz. Arch Biol Technol 48: 195-202. doi: 10.1590/S151689132005000200005

Rezessy-Szabo JM, Nguyen QD, Hoschke A, Braet C, Hajos G, Claeyssens M (2007) A novel thermostable alpha-galactosidase from the thermophilic fungus Thermomyces lanuginosus CBS 395.62/b: purifica- 
tion and characterization. Biochimica Et Biophysica Acta 1770: 55-62. doi: 10.1016/j.bbagen.2006.06.022

Shankar SK, Dhananjay SK, Mulimani VH (2009) Purification and characterization of thermostable alpha-galactosidase from Aspergillus terreus (GR). Appl Biochem Biotech 152: 275-285. doi: 10.1007/s12010$008-8271-7$

Shen WY, Jin ZY (2011) Chemical modification of $\alpha$-galactosidase from germinating coffee beans. J Wuhan Polytechnic Univ 30: 1-4 (in Chinese)

Shibuya H, Nagasaki H, Kaneko S, Yoshida S, Park GG, Kusakabe I, Kobayashi H (1998) Cloning and high-level expression of alpha-galactosidase cDNA from Penicillium purpurogenum. Appl Environ Microb 64: 4489-4494

Singh N, Kayastha AM (2012) Purification and characterization of alpha-galactosidase from white chickpea (Cicer arietinum). J Agr Food Chem 60: 3253-3259. doi: 10.1021/jf204538m
Spande TF, Witkop B (1967) Determination of the tryptophan content of proteins with N-bromosuccinimide. Methods Ensymol 11: 498-506. http:/ /dx.doi.org/10.1016/S0076-6879(67)11060-4

Steggerda FR (1968) Gastrointestinal gas following food consumption. Ann Ny Acad Sci 150: 57-66

Teng L, Fan H, Zhang Y, Yu Q, Huang Y, Liu L-y (2006) Chemical modification and fluorescence spectrum of tryptophan residues in pullulanase. Chem Res Chinese U 22: 61-64

van Bakel H, Stout JM, Cote AG, Tallon CM, Sharpe AG, Hughes TR, Page JE (2011) The draft genome and transcriptome of Cannabis sativa. Genome Biol 12. doi: 10.1186/Gb-2011-12-10-R102

Wang H, Luo H, Li J, Bai Y, Huang H, Shi P, Fan Y, Yao B (2010) An alpha-galactosidase from an acidophilic Bispora sp. MEY-1 strain acts synergistically with beta-mannanase. Bioresource Technol 101: 8376-8382. doi:10.1016/j.biortech.2010.06.045 